человека. Образовательная область "физическая культура" призвана сформировать у учащихся устойчивые мотивы и потребности в бережном отношении к своему здоровью и физической подготовленности, целостном развитии своих физических и психических качеств, творческом использовании средств физической культуры в организации здорового образа жизни.

Литература:

1. С. П. Евсеев, А. Г. Комков, О. М. Шелков Реализация личностно ориентированного подхода в процессе использования инновационных технологий физического воспитания школьников, Физическая культура, Научно-методический журнал №2, 2006г.

2. В.Н.Селуянов, Технология оздоровительной физической культуры, М.: СпортАкадемПресс, 2001г.

3. Ванесса Томпсон, Стретчинг для здоровья и долголетия, Феникс, 2004г.

\title{
ЦИТ: иа117-022
}

DOI: 10.21893/2415-7538.2016-05-1-022

УДК 796

ТАНЕЦ КАК СРЕДСТВО ЗДОРОВОГО ОБРАЗА ЖИЗНИ

Таразский государственный университет имени М.Х.Дулати.

Казахстан, Тараз, 080000

DANCE AS A MEANS OF A HEALTHY LIFESTYLE

Taraz State University named after M.Kh.Dulaty, Kazakhstan, Taraz, 080000

Аннотация. Древними индийцами было точно подмечено: «B танце сама жизнь». Танеи - это эмочии, преобразованные в движения, которые происходят в ритме современной жизни. Танщь способствуют нормализачии обмена веществ и дарят положительный заряд энергии на весь день, а так же приносят пользу для здоровья, формируют осанку, улучшают настроение, развивают чувство ритма и музыкальности.

Ключевые слова: Танеи, положительные эмочии, здоровый образ жизни, красивая осанка, заряд энергии, отличное настроение, движение - жизнь, ритм современной жизни.

Abstract. The ancient Indians were accurately noted: "In dance - life itself." Dance is emotion, transformed into movements that occur in the rhythm of modern life. Dances promote the normalization of metabolism and give a positive charge of energy for the whole day, and also bring health benefits, shape posture, improve mood, develop a sense of rhythm and musicality.

Key words: Dance, positive emotions, healthy lifestyle, beautiful posture, energy, excellent mood, movement is the life itself, the rhythm of modern life.

Наш президент Назарбаев Н.А. в своем послании «Стратегия «Казахстан 2050» четко определил свою позицию по отношению к здоровому образу 
жизни. «Здоровье - это состояние полного физического, духовного и социального благополучия, а не только отсутствие болезней и физических дефектов».

В последнее время все больше внимания стало уделяться здоровому образу жизни. Однако некоторая часть молодого поколения продолжает днями просиживать за компьютерами, в надежде сбросить вес или оздоровить свой организм. Однако в реальной жизни подобных чудес не бывает. Чтобы добиться хорошей фигуры и здорового тела стоит приложить немало усилий. Как дилемма спорту и различным видам фитнеса выступают танцы. Танец - это эмоции, преобразованные в движения, которые происходят в ритме современной жизни. $\mathrm{C}$ их помощью можно добиться незначительных результатов. Активные движения способствуют нормализации обмена веществ и, к тому же, они дарят положительный заряд энергии на весь день. Еще древними индийцами было точно подмечено: «В танце - сама жизнь». Танец способствует уменьшению мышечного напряжения . Различные движения, вращения, прыжки заставляют напрягаться все мышцы. Одновременно происходит тренировка равновесия и дыхания, улучшаются подвижность и осанка. Заниматься танцами можно в любом возрасте. Здесь нет огромных физических нагрузок, как в других видах спортивных занятий. Все зависит от танцевального опыта и возможности выполнения различных танцевальных элементов. Кто-то занимается танцами профессионально, а кто-то исключительно для себя и своего здоровья. Можно сказать, что нет человека, который бы не любил танец, не хотел бы уметь танцевать. Умение танцевать это значит становиться привлекательнее и стройнее, а свою жизнь делать насыщенней и ярче. Если ежедневно танцевать хотя бы по 20 минут, то наш организм получает мощнейшую подпитку. Любые танцы учат владеть своим телом, помогают скорректировать фигуру. Современные танцы сжигают 300 ккал за полчаса, балет, бальные танцы и чечетка - 200, народные -225 .

Существуют десятки различных танцевальных школ. Вы всегда можете подобрать то, что подойдет вам по темпераменту, и при этом будет огромная польза.

Латинскими танцами в некоторых странах официально лечат депрессию и заболевания позвоночника.

Казахский народный танец «Қара жорға» улучшает работу позвоночника. Если позвоночник здоровый и гибкий - «мысль» от спинного мозга идет быстро и прямой наводкой. Избавляясь от защемлений нервных окончаний в области поясницы и крестца, мы нормализуем работу внутренних органов.

Фламенко - прекрасный выход при лечении остеохондроза. Занятия в основном основаны на отработке правильной постановки корпуса. Это прекрасно укрепляет спинные мышцы, способствует формированию королевской осанки, распрямляет грудной отдел и плечевой пояс.

В кельтских танцах тоже заключена особая польза для человека. Такие танцы способны исправлять сколиоз и лордоз, а также выравнивать форму ног. Этот эффект достигается путем сильных движений ног и необходимости ровно держать спину. Такая необходимость стоять неподвижно и ровно приводит в 
работу практически все мышцы.

Исполнение вальса - самого романтичного и красивого танца - укрепляет нервную систему, влияет наилучшим образом на мозговую активность, укрепляет вестибулярный аппарат и наполняет чувством глубокой удовлетворенности собой и окружающим миром.

Стрип-Данс предполагает развитие пластичности каждого сантиметра вашего тела, начиная от пальцев на ногах и до кончиков пальцев рук! Данный стиль - находка для суставов (развитие их подвижности), а также обретение пластики.

Индийский классический танец - это мощное средство для того чтобы прогнать ненужные мысли, снять стресс, а также обрести или вернуть уверенность в себе.

Танец Фокстрот - является отличным способом профилактики сердечнососудистых заболеваний, помогая поддерживать здоровье и улучшать дыхательную функцию сердца. Кроме этого, танец увеличивает силу и мышечную выносливость, а также способен стимулировать правильную осанку.

Боди-Балет. Стиль, который полностью противопоказан тем, кто страдает от варикоза. Основной упор в занятиях танцами в этом стиле делается на ноги, что позволяет в максимально короткие сроки сформировать и проработать каждую мышцу ваших ног и ягодиц и придать им именно ту форму, которая на ваш взгляд будет идеальной.

Танец живота забота об упругости вашей кожи, и укрепление мышц спины, и вибромассаж посредством тряски, что заметно убирает лишние сантиметры с бедер и ягодиц, а также подтягивает мышцы живота.

7 причин заняться танцами:

1.Польза для здоровья

2.Хорошая осанка

3.Красивая походка

4.Общение

5.Снятие мышечных зажимов и улучшение настроения

6.Развитие чувства ритма и музыкальности

7.Гармоничное развитие и улучшение внешности

У людей, занимающихся танцами гораздо выше жизненный потенциал. Можно предположить, что при постоянных, настойчивых занятиях танцами этот процент будет постепенно уменьшаться. И, конечно, благотворное влияние танца на человека ощущает не только сам танцующий, но и люди его окружающие. Самыми распространенным заболеванием стала гиподинамия недостаточность движения. Очень уж обездвиженной стала наша жизнь. Дальнейшая жизнь и работа тоже не требуют движения. От подвижных нагрузок освобождают человека различные механизмы и машины. Однако человеческий организм рассчитан на движение. Медики говорят, что эластичность и крепость стенок кровеносных сосудов формируется только при физических нагрузках. Если таковых нет, то человеку грозят многие заболевания. Танец, безусловно, способен спасти, и спасает многих от этого. 
Танцуйте! Вы станете доверять себе, почувствуете жажду жизни - ведь если можно красиво двигаться, значит, можно красиво жить!

Литература

1. Зись А. Виды искусства. - М.:Знание, 1979.- с. 67-71.

2. Келдыш Ю.В. Музыкальная энциклопедия. -М.: Советская энциклопедия, 1981. - с.423-424.

3. Косачева Р. О музыке зарубежного балета. Опыт исследования. -М.: Музыка, 1984. - 304 стр.

4. Пасюковская В. Волшебный мир танца. - М.: Просвещение, 1985. - 224 стр.

ЦИТ: иа117-048

DOI: 10.21893/2415-7538.2016-05-1-048

УДК 37.037

\section{Ворок С. С., Гаврилова Л. О. \\ СУЧАСНІ АСПЕКТИ НАВЧАЛЬНОЇ ДІЯЛЬНОСТІ МАЙБУТНІХ ФАХІВЦІВ У НАПРЯМКУ ПІДГОТОВКИ «ФІЗИЧНЕ ВИХОВАННЯ»}

Військова академія,

Одеса, Фонтанська дорога, 10, 65009

Vorok S. S., Gavrilova L. O.

MODERN ASPECTS OF EDUCATIONAL FUTURE SPECIALISTS IN THE AREAS OF TRAINING "PHYSICAL EDUCATION"

Military Academy

Odessa, Fontanska Road, 10, 65009

Анотація. У статті розглядаються актуальні проблеми освітньої діяльності військових фахівців з фізичного виховання курсантів. 3 урахуванням основних етапів освітнього процесу сформульовані основні проблеми сучасної освіти в галузі фізичного виховання. Показано переваги кредитно-модульної системи вищої освіти, яка стимулюе систематичність, активну и рівномірну роботу курсанта на протязі навчального часу. Вказані різні методи модульного навчання, особливо підкреслена роль технічних засобів навчання, використання яких в освітньому процесі значно підвищує засвоюваність курсантами отриманої інформаџії. Відзначено, щуо в кредитно-модульній системі дуже важлива самостійна робота курсантів, яка вимагає не тільки постійної уваги, але й суворого контролю і оиінки результатів. Розкрито роль $i$ функиії контролю освіти як способу перевірки знань, навчання курсантів $i$ здійснення зворотного зв'язку «курсант - викладач». Відповідно до вимог часу освітній прочес повинен бути насичений иілеспрямованою систематичною самостійною роботою курсантів з електронними базами даних, що значно підвищує його ефективність.

Ключові слова: освіта, навчальний прочес, курсанти, фізичне виховання, кредитно-модульна система.

Abstract. In the article actual problems of educational activity of military 